\title{
Improvement of Internal Audit System in the Institutions of the Public Sector in Russia
}

\author{
Kosteva N.N.* \\ Voronezh State Agrarian University \\ Voronezh, Russia \\ E-mail: natallia.79@mail.ru \\ Kopytina M.K. \\ Voronezh State Agrarian University \\ Voronezh, Russia \\ E-mail: milli33@mail.ru
}

\author{
Pavliuchenko T.N. \\ Voronezh State Agrarian University \\ Voronezh, Russia \\ E-mail: pavlychenko_tn@mail.ru \\ Bunina E.Y. \\ Voronezh State Agrarian University \\ Voronezh, Russia \\ E-mail: apom84@mail.ru
}

\author{
Shamrina I. \\ Department of Accounting, Auditing, Statistics \\ Financial University under the Government of the Russian Federation \\ Lipetsk branch, Russia \\ E-mail: IVShamrina@yandex.ru
}

\begin{abstract}
The subject of the study is the problem of organizing internal control in budgetary institutions. The article discusses the theoretical issues of the formation of the system for internal financial control carried out by budgetary organizations of our country. The relevance of assessing the effectiveness of internal financial control in budgetary institutions is determined. The main shortcomings and problematic issues on the organization of internal financial control in the public sector are shown. The need to organize internal control in budgetary institutions does not raise any doubts, not only within the framework of the legislative obligations, but also because of the recognition of the need for effective supervision of the spending of budgetary funds. Control is the main independent source of information for identifying the causes of abuses arising in the process of managing public finances and state property, as well as an effective means of influencing decision-making to prevent certain violations. In such circumstances, the importance of internal control in budgetary institutions is constantly growing. With this in mind, the article reports the study of the features, content, and tools of internal control, as an element of preventing violations in the accounting of a budgetary institution. In the process of analysis, the relationship between the effectiveness of accounting systems and the internal control, which is inversely proportional, is examined. Special attention is also paid to the methods of internal control, self-control, control by the subordination level, control by the jurisdiction level, and the procedure for conducting joint control. The transition to the digital economy, the structural changes resulting from this, and the totality of theoretical, methodological, and practical issues related to the development of organizational and procedural support for internal financial audit entities in the public sector organizations are relevant and most interesting for scientific study. Over the past decade, a radical change in the organization of internal financial audits has taken place, associated with the implementation of international norms and standards in the legislation of the Russian Federation. In accordance with the international concept of state internal financial control, a
\end{abstract}

distinction is made between the functions of internal control and internal audit.

Keywords - internal financial control, internal audit, public sector of economy, internal audit standards for the public sector organizations, finance management quality control.

\section{INTRODUCTION}

The nature of public financial resources management in the industry is such that the problem of finding an effective budget funds management system is highlighted, in which state financial control occupies a special place as a strategic motivator for the efficient use of public financial resources [1] Therefore, the theoretical and practical aspects of improving internal audit in the public sector in the current situation occupy the key place.

Today, there is an urgent need for significant increase in the efficiency of the use of budget funds, the quality and effectiveness of internal financial control and internal financial audit systems [2]. The systems of internal financial control and audit are present in government bodies, but executors incorrectly position the term "internal financial control" as control and supervisory activity within the authority over its subordinate bodies and institutions. The system involves duplication of powers of state financial control bodies and the powers of the founder in the field of financial control. However, the acts of the institutional basis speak of the creation and functioning of internal financial control systems for the audit of the executive branch itself which should be rightfully called the internal financial control of internal budget procedures, the audit of the reliability of the internal control system and budget reporting.

State financial control is the activity intended for timely identification of any deviations from accepted standards, 
violations of the principles of efficiency, legality, effectiveness and economy of financial resources management in order to make adjustments, strengthen the responsibility of authorized persons, compensate for damage, create interference, and complicate the repetition of violations in the future [3].

In accordance with international practice, the system must be considered as a continuous process within the executive authority, aimed at:

1) compliance with the established procedures for the preparation and execution of the budget;

2) compliance with the established procedures for the preparation of budget reporting and budget accounting (ensuring the reliability of budget reporting);

3) preparation and implementation of the measures to increase the efficiency and performance of the use of budget funds.

At present, the participants in the budget process, mostly understanding the system of internal financial control and audit as a "special" obligatory budgetary power, excessively formalized by the regulator - the Ministry of Finance of the Russian Federation, justify the need to increase the number of staff and financial support in order to ensure its quality implementation.

In its turn, the Ministry of Finance adopted the necessary regulatory legal, methodological, and organizational documents necessary for public authorities to implement and operate internal financial control and financial audit systems. Despite the differences in opinions of the representatives of the subjects of control and audit, they agree on one thing: at present they require organizational solutions to a number of procedural and methodological issues necessary to ensure the effectiveness of the created systems of internal financial control and financial audit.

\section{PROBLEM STATEMENT}

The basis of the rational approach to the formation of effective systems of internal financial control and financial audit is the identification and assessment of budget risks which are possible events that adversely affect the implementation of budget procedures in the following areas: probability of occurrence and consequences of their realization.

When assessing the probability, the conditions of the occurrence of a negative event are considered, both in order to determine the degree of probability, and in order to determine measures to mitigate the corresponding causes and conditions. The degree of risk influence is determined on the basis of whether the considered negative event leads to a gross violation in the financial and budgetary sphere (a significant decrease in the value of the financial management quality indicator) or not [4].

According to the results of the budget risk assessment, it is first of all necessary to determine the risk-intensive operations for inclusion in the risk-card and the nature of the control actions necessary for timely suppression of the implementation of significant risks. With this approach, the most effective are automatic control actions carried out using information systems that ensure the implementation of internal budgetary procedures, with automatic data recording on violations (errors) and their correction in the register of the results of control actions.

The most important source for working with risks during the formation of risk-cards should be the information on the results of control and analytical measures of state (municipal) financial control bodies, the results of monitoring the quality of financial management, received by the chief administrator of budget funds on a regular basis, as well as the results of an internal audit.

The second stage is the harmonization of the internal control system with the budget risk management system of the chief administrator of budget funds, transformation into a system for improving the quality of financial management.

At this stage, internal financial control should become an integrated system of budget risk management. This means not only the implementation of checks on the operation executions based on the risk assessment, but also the elimination of the reasons for the implementation of risks that lead to violations, failure to achieve the target values of financial management quality indicators.

Moreover, such work should be carried out according to the levels of subordination: at the level of the chief administrator of budget funds, at the level of department heads, and at the level of ordinary employees of departments of the chief administrator of budget funds. As a result, for each significant budget risk, measures are identified to eliminate the causes of its occurrence.

Such measures may include the following ones:

- clarification of regulations for certain procedure performance;

- clarification of control measures in relation to the procedures performed within the framework of financial management;

- organization of staff events;

- advanced training of employees performing operations (procedures, actions), which are accompanied by risks to be minimized;

- re-allocation of responsibilities within the structural unit, the activities of which involve risks to be minimized;

- purchase and commissioning of equipment, automation, software, other tangible and intangible assets necessary to minimize risk;

- organization and monitoring of changes in budget legislation in order to timely inform the responsible staff of the comprehensive information necessary for the correct performance of operations;

- other measures that may lead to risk minimization. 
We should achieve an effective relationship between internal control systems, financial management quality assessment, and the state financial control system. At the same time, most of the violations and deficiencies in the financial and budgetary sphere should be detected and eliminated within the department as a result of the work of the internal auditor.

The final and logical step will be to extend the scope of internal financial control to all institutions in the public and governmental sector.

\section{ANALYSIS}

The modern budgetary process requires compliance with financial and budgetary discipline from all participants in the allocation and use of public funds, which is ensured by a system of effective and successful control. The organizational imbalances typical for budgetary institutions, as well as the instability of their financial condition, determine the urgent need for the introduction of internal control in all areas of their operation and functioning [5].

It should also be noted that the internal control system of a budget institution and its accounting system are interconnected. That is why, in the process of studying the accounting system, the internal control system is determined as a component of the accounting system. And vice versa, when studying the system of internal control of a budget institution, one of its mandatory elements is the accounting system.

The published Treasury report [6] shows the following key weaknesses in performing internal financial control:

1) There are institutions that do not have approved legal acts on internal financial control performance.

2) There are no powers to exercise internal financial control in the staff regulations.

3) There are cases of inconsistency of regulatory acts of chief administrators on internal financial control with the provisions of regulatory acts of the Ministry of Finance.

4) Not all structural units responsible for the implementation of internal budget procedures keep the registers; the frequency of providing information to the management (or its deputies) on the results of internal financial control is not set.

5) The budgetary powers to keep internal financial control are not always exercised.

6) The procedure for exercising internal financial control has not been developed.

7) The procedure for keeping and filling in the registers of internal financial control has not been established.

8) There is no regulatory act setting the procedure for reporting on the results of internal financial control and the procedure for bringing it to the authorized person (or his deputy).

9) No operations (actions on the formation of documents necessary for the implementation of the internal budget procedure) were identified in the divisions of the chief administrator of the funds responsible for the implementation of internal budget procedures.

10) There are no approved cards of internal financial control; updating of the card of internal financial control is not carried out.

11) The requirements established by the cards of internal financial control concerning the frequency of control actions, methods and ways of control are not complied with, etc.

Thus, in the presence of the problems listed above, in a number of budgetary institutions, an effective system of internal financial control is not organized and does not adequately meet the legal requirements, or is carried out just formally.

Taking into account the above, improving and increasing the efficiency, quality, and reliability of accounting in a budgetary institution, in the context of developing an internal control system, by strengthening the managerial, control, and information functions, is an important task that requires indepth development and analysis in the process of reforming accounting in state institutions [7].

At the same time, despite significant achievements in the field of clarification and development of state (municipal) internal control procedures, there are still many unresolved issues related to the prevention of violations of the law in the process of distribution and use of budget funds, as well as in the context of ensuring the interests of the state in managing objects of state property.

The system of internal control over the spending of budgetary funds provides for verification of authorization procedures and permits. All business operations of a budgetary institution must be authorized by the responsible departments (employees).

The functioning of the internal control system of a budgetary institution is confirmed by arithmetic and accounting controls, namely, the completeness and accuracy of accounting for business transactions is checked.

Examining the relationship between the effectiveness of the accounting system and the internal control of a budget institution, one can observe an inverse proportional relationship.

As international experience shows [8], the public sector functions efficiently when financial management is monitored to ensure compliance with standards across the entire vertical: from a budget institution to the key manager of public funds.

In the implementation of internal financial control, the following methods of internal financial control are used: selfcontrol, control by the level of subordination, joint control, and control by the level of jurisdiction.

Self-control is carried out by an official of each structural subdivision of the chief administrator (administrator) of budgetary funds by checking the operations carried out by it for compliance with the requirements of legal acts regulating budgetary legal relations and (or) determining the expenditure (budgetary) obligations, requirements of internal standards and procedures, and job regulations, and (or) reconciliation of 
data, as well as by assessing the reasons that negatively affect the operation.

Control by the level of subordination is carried out in a continuous way by the head (deputy head) and (or) the head of the unit of the main administrator of budget funds (or another authorized person) by confirming (coordinating) the operations carried out by subordinate officials.

Joint control is carried out in a continuous and (or) selective way by the head of the unit of the main administrator of budget funds (another authorized person) by coordinating (confirming) the operations carried out by officials of other structural units of the main administrator of budget funds, and (or) by reconciliation of data, as well as analysis and evaluation of information on the results of the implementation of internal budgetary procedures.

Control by the level of jurisdiction is carried out in order to exercise budget powers by the chief administrator (administrator) of budget funds in a continuous and (or) selective way. This happens by conducting inspections aimed at establishing the conformity of the submitted documents with the requirements of the legal acts that regulate budgetary legal relations and (or) stipulate budgetary obligations. The inspection consists of procedures for collecting (requesting), analyzing and evaluating performed by the chief administrator (administrator) of budget funds concerning the information about the organization and the results of the implementation of internal budget procedures by subordinate administrators of budget funds and recipients of budget funds.

The results of such inspections are drawn up by a conclusion indicating the need for corrections and (or) elimination of deficiencies (violations) if they are observed within the time period established in the conclusion or by a permit inscription on the submitted document.

Based on information from primary documents, operational and business accounting, internal control allows monitoring and regulating business situations, preventing outgoings and losses, preventing financial irregularities, and thus implementing preventive regulation of deviations.

The internal control system of a budgetary institution ensures the implementation of the mission and the goals of its creation, which are to preserve its property. It also significantly affects the identification and mobilization of existing production reserves; contributes to the efficiency and quality of the budget institution performance; allows increasing savings, identifying the causes and conditions that contribute to the occurrence of fraud, shortages, and theft of property.

In the process of conducting internal control when checking the accounting information of a budgetary institution, it is necessary to analyze all possible operations with assets: income, disposal, depreciation, repair, rental, liquidation, etc. It is advisable to pay special attention to comparing the data in the primary documents with accounting registers and reporting forms in order to provide the decisionmaker with confidence in the reliability of the data on the accounting of transactions for further substantiation of his management decisions. There is no doubt that all the objects of operational management in a budgetary institution should be influenced by the internal control function. It is designed to provide the possibility of implementing and improving the management process both by clearly identifying the deviations from planned tasks, norms, and standards, and by intervening in the field of planning, accounting, analysis in order to identify shortcomings, violations that reduce the quality of these functions, respectively, negatively affecting management process.

In order to prevent violations in the accounting of a budgetary institution, the internal control system should combine various forms, tools and methods of control procedures, such as internal inspection, structural and functional control, internal audit, and also create conditions for the implementation of the control mechanism of a budgetary institution.

Based on the above, despite the existence of an internal and external evaluation of internal financial control, the main purpose of any assessment is to analyze the system and the results of internal financial control, to identify weaknesses in the organization of control, and to offer recommendations for improving the functioning of the institution's internal financial control. It is impossible to imagine a further increase in the effectiveness of internal financial control without a periodic assessment, analysis of its implementation, as well as the introduction of new, modern ways of organizing it at all possible levels of the system.

\section{CONCLUSION}

The function of internal financial audit, which is carried out in order to assess the reliability of the system of internal financial control, confirm the reliability of budget reporting and formulate proposals to increase the economy and effectiveness of the use of budget funds, is currently at the formation stage.

In accordance with international standards of internal control in the public sector, the structural unit performing internal audit should be independent and report directly to the organization's management about the results of assessing the quality of internal controls and risk management [9]. At the same time, the audit of financial (accounting) statements is one of the areas of internal audit. In this regard, internal financial audit should be considered as a transitive form to internal audit in organizations of all fields of the public sector.

The final result of the internal audit is not reporting on the violations identified, but confirming the reliability and effectiveness of management and control procedures in the organization, as well as generating recommendations to improve their quality.

Accordingly, it is advisable to define internal financial audit in the budgetary legislation as an activity to provide independent and objective information on the quality status of the budget funds management system of the chief administrator of budget funds.

The next task is to ensure the functional independence of the internal financial audit units and the organization of training for internal auditors. 
For most chief administrators of budgetary funds, the creation of large separate internal financial audit units (department, bureau), directly reporting to the department's management, is unrealistic and economically unjustified based on the goals and objectives of the internal financial audit. In order to comply with the principle of functional independence, small units of internal financial audit should be created as part of other units that do not carry out internal budget procedures, or directly subordinate them to the head of the main administrator of budget funds.

Also, training programs for specialists in the field of internal financial audit and their practical training should give them a clear understanding of the provisions of the standards and methodologies for internal financial audit, especially in terms of assessing the reliability of internal financial control, understanding the fundamental differences between the internal financial audit function and any control and inspection function.

Another important task for strengthening the function of internal financial audit is to develop approaches to conducting an internal audit of the reliability of the budget statements of the department and their consolidation in the legal field.

Due to the fact that a complete inspection of the budget reporting indicators is practically unrealizable due to the limited material and labor resources and, in principle, is irrational, the audit of statements should be carried out using risk-oriented methods, involving the identification and assessment of risks of a significant distortion of budget reporting, using this assessment to determine the nature, timing and extent of audit procedures. The internal auditors conducting a quality audit of the budget statements using riskoriented methods before submitting them to external users will ensure its reliability and significantly reduce the risks of significant distortions in the reporting on the execution of the respective budgets.

The complete implementation of these tasks for strengthening the internal financial audit function will allow the authorities to gradually move to the organization of a general internal audit in departments, within the framework of which the following tasks should be solved:

- intra-departmental assessment of the quality of management and control of the processes ensuring the achievement of target indicators of state (municipal) programs;
- analysis of the management decisions on financial support of the institution;

- confirmation of the reliability of budget statements

Therefore, it is necessary to transform the system of internal financial control and internal financial audit, to determine their places and roles in the financial management system. To do this, it is necessary to create certain conditions necessary for the implementation by each state authority body of the decisions on the design of the system of internal financial control and internal audit, ensuring the real achievement of the goals that are laid down in the Budget Code of the Russian Federation

The implementation of the measures described above to improve the internal financial control and internal financial audit systems will turn these systems into an effective tool for improving the efficiency of budget expenditures.

\section{References}

[1] R. Ricciuti, A. Savoia, K. Sen, "What determines administrative capacity in developing countries?", Int. Tax And Public Finance, vol. 26, iss. 5 SI, pp. 972-998, 2019.

[2] M.A. Volkova, E.D. Solomatina, N.V. Shabutskaya, T.V. Sabetova, E.A. Shubina, "History Of Views On Audit Of Commercial Structures Management Quality", Contribut. to Econ., no. 9783319454610, pp. 81-90, 2017.

[3] S. Camussi, A.L. Mancini, P. Tommasino, "Does Trust Influence Social Expenditures? Evidence from Local Governments", KYKLOS, vol. 71 iss. 1, pp. 59-85, 2018.

[4] O. Varon, H. Fabio Rios, N. Manolo Chavez, "Budgetary Deficit And Inflation: Case The Pacific Alliance", Dimens. Empresarial, vol. 16, iss. 1, pp. 135-146, 2018.

[5] R. Jones, J. Llewellyn, "Maintaining Stable Macroeconomic Conditions", National Instit. Econ. Rev., vol. 250, iss. 1, pp. R7-R14, 2019.

[6] Report of the results of the internal financial control and internal finanical audit performed by the chief administrators of the funds of the federal budget fulfillment in 2019. Retrieved from: http://www.roskazna.ru/kontrol/analiz-

[7] Y. Kim, D.S.T. Matkin, "Financial Condition and Internal Control Deficiencies: Evidence From New York Counties”, Public Budget. And Finance, November, 2019.

[8] A. Bolton, A. Thrower, "The Constraining Power of the Purse: Executive Discretion and Legislative Appropriations", J. of Politics, vol. 81, iss. 4, pp. 1266-1281, 2019.

[9] A. Wildowicz-Giegiel, "The role of independent fiscal councils in improving fiscal performance of the European Union countries", Equilibrium-Quarterly J. of Econ. and Econ. Policy, vol. 14, iss. 4, pp. 611-630, 2019. 